\title{
中国語語気詞の意味記述 (その1)
}

大滝幸子

为了記叙中文语气助词的含意, 感 觉过去两种方法均有缺点, 不能把握 语气助词唯有的意义来。

语气助词的意义慈並非被文, 或语 调的含意所左右，而是由於「叙述内 容」「述定」「传达」各别所持之特征。 我为探究清楚语气助词的意义紊, 对某一中国人的言语，予以分析, 其 结果如下。

语调上昇「ノ」的意义亲是「说话 的人不能下确定判断」, 语调下降 「」的意义素是「说话的人能下确

1. まえがき

2. 語気詞の意味記述法

2.1 語気詞の意義素の抽出

2.2 用例の集収法

3. 音䚴の昇降による意義素の把握

3.1 文音菃厂，〉

3.1 .1 音調の形

3.1 .2 文音調の意義素

3.1 .3 分句中で音謂の意轹素

\section{1. まえがき}

中国語語気詞の意味記述法としては，従来 主に次の二通りの方法がとられてきた。

（i）語気の表わす意味を，筑問，祈使紮止， 測度, 陳述, 停頓, なとに予め分類して おき，次に各々の語気詞の意味をこれら の分類に当てはめる”。

(ii）語匃詞一つ一つについて, 幾つかの用 法を列挙していく2。 ところがここれらの記述法では，語気詞
定判断」，都是仅与述定有关的。

呵上昇调「ノ」的意义竞是「说话 的人透听话的人接妥自己的意见，啊 下降调「】」的意义美是「说话的人 不表明其本来的测度」都是仅与传达 有关的，

吗上昇调「ノ的意义美是「对听话 的人问是否」，吆下降调「】」的意 义紊是「说话的人以为自己的意见是 很有理, 叫听话的人稳成它」与「述 定」「传达」两者俱有关连。在分句 中的么不是语气助词，屈於别的词类。

$3.2 \mathrm{a} /, \mathfrak{a} \searrow$

$3.2 .1 \mathrm{a} /$ (高軽声), a】(低軽声) の形

$3.2 .2 \mathrm{a} \nearrow, \mathfrak{a} \backslash$ 羔義素

3.2 .3 具体例での検部

$3.3 \mathrm{må} \nearrow, \mathrm{má} \searrow$

3.3.1 $\mathrm{ma} /($ 高柽声), $\mathrm{må} \backslash($ (低㹩声)の形

$3.3 .2 \mathrm{må} /$ må】の意毒素

3.3 .3 分句中の må/と må】

4. まとめ

の意味の中に，文の意味や音調の意味，さら には文脈・場面によって作り出される随時的 な意味までもが織り込まれがちで, 各々の語 気詞がもつ意義来を明礁にしがたい。

そこで，本報告ては，語気詞の意義素を より明確に把握するため, 上記の記述方法に 依存しつつも，なお多くの補足事項を加え， 秩序だった意味記述法を翟いたろえで，その 有効性を具体例について湌就した。 
2. 研壱詞の意味記述法

2.1 語気詞の意莪素の抽出

まず，語気周の意義素と文の意味とが混り 合わないように，国語学における陳述碖に基 つき"，文（文の意味）を，句（叙述内容） と，陳述（述定と伝達）とに分ける。この考 え方に拋り，著者は語気詞を棵述を權成する 品詞として扱らことにした。また，文音調い をも陳述を權成する言語形式の一つとして語 気詞と同等に扱うことにした。

そこで，本報告では語気詞の意䕊素におけ

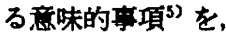

(i) 叙述内容

(ii) 述定

(iii) 伝達

の三項目とする。そして，インフォーマント によってなされる内省報告を，この三項目に 関するとのような意義特徴を含んでいるかと いう襀点から整理検討する。

\section{2 用例の集収法}

語気詞の用法は, 個々人の出身地, 性別年 峆，性格等により，差具が大きいといわれる。 本報告では調査対象を程㳔路氏日) の個人言語 とし，資料の均資性を保とろとした。さらに， 個人的な要因に﨏る影郚をでき得る限り排除 し，普逗性を高めた资料を得るためと，語気 詞の意味を的磧に把暒するために，同一の語 気詞について簧なる用例を多方面に渡り集め ることにした。

そこで，まず語気詞の意味の差が形として 明確に顕われるように，句の意味や形を陳述 との係わり方に拋って，表 1 のように分類し た。次いで，分類に適合する用例を多くの文 献”より集め，振り分けた。そのうえで，表 1 中の の位睡に音調と語匃詞とを順次付り 替えることによりできあがる文に対し，イン フォーマントの内省報告を樂めた。

本報告では，表 1 中の(1)がすべての語気詞 の意義素を取もよく弁別しうる用例であると
判断し，以下のような言葉を用いてなされた 内省報告をまず分析整理した。

肯定, 确定, 推测, 劝告、提醒, 命令指 示, 没把暒地告诉人家，疑问，加强语气 自大, 意外，感叹，很有礼䡚，分辩，反 诘，指紊，竞难，不满，

分析結果は表 2 のように整理される。表 2

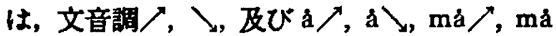
】の意義来抽出に役立てた。ただし，表 2 中の $* * * *$ ，の用語は，次のように定䇅した。 *述定は，話し手が叙述内容の現実性また は真理性に対してどのような意見を持ってい るかを表明する言語行動の名称である。ここ で現実性 ${ }^{8)} と は ，$ 叙述内容が現実となる可能 性を意味し，発話場面における言外の事情に

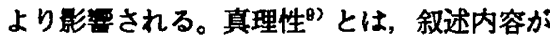
真理と一致する可能性を意味し，話の筋道や 話し手の信条に関わるものである。

** 発話時点 ${ }^{(0)}$ とは，発話が行なわれている 現実の時点を意味する。それに対し，叙述内 容の中で定められた話の時点を叙述時点とよ ぶことにする。

\section{3. 音調の昇降による意維素の把握}

\section{1 文音䚴 $\nearrow$, 】}

\section{1 .1 音調の形}

本稿では，文音調として㫒り音調ノ，と降 り音調】，および強調の音調とを探りあげた。 強調の音調を採りあげた目的は，インフォー マント自身が平常使用している昇り音調と降 り音調との違いをまず明確に判別できるよろ にすることと，叙述内容に引きつられた無意 識の強調を行なわないようにすることである。 したがって，强調の音調として扱かった形は， 文末の音調变化の帯域を扰大したものに限っ た。会話速度の変化，及び声色・声量の変化 なと，生理現象や対人感情に密着した形のも のは採りあげなかった。

\section{1 .2 文音調の意菚素}

表 1 に示した例句に文音䐓のみを加えて文 
を形成した場合，加える音調がノ，】のとち らであるかによって生しる意味の差を表 2 に 照らしあわせて概括すると，表了のよろにな る。ただし，表 1 の(5)(6)(7)では，分句中で用 いられる音調を扱うことになるため，項を改 めて詳述することにした。表了によれは，ま ず，文末音調の強調が「韭し手の述定のあり 方をより明磪にする」ことが䆧い知れる。す なわち，强調音調のもたらす表 2 中のA愐 $\rightarrow$ $B$ 項, $\mathrm{B}^{\prime}$ 項 $\rightarrow \mathrm{C}$ 項といろ二つの意味爱化は上 記の点で共通点を有するものと考えられる。

そこで，演擇的に検討してみると，平常の

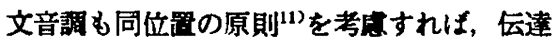
のあり方を定めているのではなく，述定のあ り方を定めているむのと考えられる。すなわ ち，文音調/は，噼問の一タイブを表わすと いうょりも，「述定のあり方が定まらない不 安定さ」を表わすむのと考えられる。

また，文音調】は，「述定のあり方が確定 しているという安定感」を表わすむのと考え られる。

以上のような演程的な解釈に従うと, 初め て以下のような言語事実を統一的に把握でき るようになる。

(1) 文音調ノが表わす表 2 中のA項の意味 は，話し手の心むとない様子をみて聞き手の 方が自然に何か自分の意見を述へてみたくな る，という人情の機微に由来するむのと考え られる。このことは，(i) A項に含まれる三 種の問いかけが，場面・文脈次第でとの例句 についても表現できるという点て確証を得た ことと，(ii) インフォーマントに話し手とし ての意困と，開き手として受ける印象とを区 別して内省報告してもらうこととにより確か めている。

(2) 文音調は，表 1 の(10)及び(11)につけて用 いられると, 表 2 中のC項の意味（こんなこ とも知らないのか!一体とういうつもりなの か!なと）を表わすことになる。これらの句 では叙述内容の中で確証のない部分が, 単語
連結 ${ }^{22}$ のパターン或いは疑問詞によって明示 されている。そのうえ更に，述定のレベルて 話し手には確信がないことを表明するとなる と, 叙述内容の中で確靽のない部分は，あた かも閶き手にとって確証のない部分であるか の如くに述へることになるものと考えられる。 このような意味の共起反応は, 叙述と述定と いう異なった意味レベルに渡って生じるもの でりり，話し手や间き手を対話における通常 の役割から逸脱させるものと考えられる。そ して，これはその内の「聞き手を主体者吕) 誘运する反応」として捉えることができる。 その被なニュアンスは，次のような日本語 に訳しだすこともできょう。

表 1 の $100-\mathrm{a}$ - 你明儿出去不出去 $\nearrow ? ~ ?$

あなた，あした本当にでかける気ノ？

表 1 の(11- $\mathrm{a}$ ・你都到过哪儿 $\nearrow$ ?

あなたは一体とこへ行ったというのノ?

3.1 .3 分句中での音調の意義素

文音調が文を成立させるのに充分な阵述の 意味を表わすものとされている以上, 分句中 に使用される音調を文音調と同一視して扱了 ことはできない。本稿では，これを「句音調」 と呼ぶことにする。そして，句音調の表わす 意味を以下の考え方に従い，分析することと した。

まず，㴖辺 1971．の概念に基つき，話し 手14が様々な意困を抱きつつ叙述内容を抽き あげていく言語行動を「叙述の学み」と呼ふ。 叙述の営みは，伝達や述定から数段階にわた る抽象過程を経るものとし，かつ伝達や述定 と様々な意味の共起反応を結ふすのである。 次に，本稓では，云達を叙述の営みの際中に む顥われるむのとするのに対し，述定を叙述

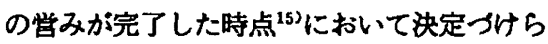
れるものとする。なぜならば，言語行動を起 こす動機のうち最も䝠始的なものは, 他人と の意志㻋通を求める心であり，伝達に関する 意味こそ言語行娌の基艋として常に顕われる 機会を有し得るものと考えるからである。 
さて，そこで，句音調の意味を表 1 中の(5) (6)(7)の用例を用いて噌理検时してみると，表 4のようになり，句音調の意味は表面上二つ のタイプにわかれる。

ところが，句音調ノは，「叙述の営みを繶 けていくこと」を表わし，句音調】は，「叙述 の学みを僖止すること」を衰わすむのと考え るならは，上衭の二つのタイプは前句の形の 遗いによって生しるものにすぎないものとみ なしろる。

表 4 中に示したA夕イプでは，闑き手の側 からは音調ノ，】が句音調であるか文音調て あるかを予測することはできない。ただ文 眽上の充分な表づけがある場合や，語尾の長 さ，音域，発話の速度に工夫が加えられてい る場合は別である。しかし，いつれにしてむ 本稿では言語の意味を話し手の側から捉える べきものとしているので, 句音調と文音調と を明らかに翼なるむのとして扱うことが可能 である。

表 4 中に示したBタイプでは，句音調ノを 用いると，叙述の営みの継統を重罡して保証 することになり，その結果，閶き手にしつこ さや费みを感しさせるむのと考えられる。こ のような意味の共起反応は，同じ叙述の営み のレベルで生しるものであり，話し手の意図 をより明確にするむのと考えられる。そして， これはその内の「重ね表現によるダメ押し」 として据えることができる。

さて，表 4 中の*で示した例外を解积する ためには，中国語の仮定法の中での「要是」 の役割を考察する必要がある。すなわち，

表 1 の(7)-c ・要是你做买卖 ，可以发 财了。

表 1 の $(7)-b$ - 就是你来请 , 我也不去。

補足例你做买卖的话, 可以发财了。 において，(7)-c と補足例においては，前分 句と後分句とで副詞の呼応がみられない。こ れらの例では話し手が閒き手にも後分句の結 䛫について億測したり自主的に判断を下した
りする「參加の自由」を残している。それに 対し(7)bにおいては「就是〜也〜」という習 買として固定された副詞の呼応が用いられて いる。それゆえ，話し手は仮定をたてた当初 より結硂を独断て用意して話しを進めていく 姿势をうちだすことになり，闒き手に参加す る余地を残していない。したがって後者の例 においてのみ，ダメ押しの表現が成立すると 考えられる。ただし「要是」と「就是」とを，

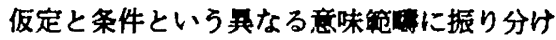
ることにより，新しい考察も可能となろう。 これは今後の課題とする。

\section{$3.2 \mathrm{a} /, \mathrm{a} \backslash$}

$3.2 .1 \mathrm{a} /\left(\right.$ 高蛏声), $\mathrm{a} \backslash\left(\right.$ (低怪声) の形 ${ }^{15}$ ) 語笠詞 $\mathrm{a}$ は，特殊な強調が加えられない限 り，轾声て用いられる。したがって，aノａ 】，の表わす形は，図 1 に示した(A)(B)のどち らかのタイプになると考えられる。

図 1 a八, àの表わす形

\begin{tabular}{|c|c|c|}
\hline & (A)タイプ & (B)タイプ \\
\hline $\begin{array}{c}\text { 通常の } \\
\text { 㹩声の } \\
\text { 高さ }\end{array}$ & $\left\{\begin{array}{l}a \\
a \\
a\end{array}\right.$ & : \\
\hline & 京`が全体的にうわずる & a \が全体的に二低くなる \\
\hline
\end{tabular}

本報告のインフォーマントは(A)タイプの無 音をした。また，老人の中には、】で反詰を 表わす人もいるとのことであり，インフォー マントは，(B)タイプの発音でロまねをしてみ せた。

\section{$3.2 .2 \mathrm{a} \nearrow$, à \の意義素}

aノ，àについての内省報告を表 2 に照ら し合せ概括し，整理するならは，a/は表 2 中のC項の意味を表わし，àはB項の意味 を表わす。

ただし，̊】の整理については次の二点に 留意した。（i 当初の内省報告では，しはし は「丁等な言い方」という表現が用いられた。 しかしそれは，話し手の感嗼（慨慕，嘆等 
を含む)によって生じる開き手の印象である とみなした。すなわち，感嗼を「発話時点に おいて話し手の意見が変わることに掩って生 ヒる感情」として捉え，聞き手に対しても臨 軥感あふれる人間関係の機微を忽しとらせる ものと判断したからである。(ii) 表1の(1)に ついては, 表 2 中のA項の一部「请柋详细告 诉我吧」という锭問を表わすという内省報告 があった。しかしその意味は単独で報告され ることがなく，常に感嗼と組になって報告さ れた。そのため，忽楞と関連性のある疑問で はないかと考え，インフォーマントに磪かめ たところ、「話し手があまりに駧ろいている 場合には，開き手の方が進んで説明を加えて やる」といろ，対人夙保を円滑にする一つの 習拪がミ】の表現によって催がされることが わかった。

また，分句中におけるaノ，a】の意味は句 音調の表向きの意味が二つにかかれるにもか かわらず，常に句末に配置された場合の意味 と同しであった。このことから, a/, a \の 意義素は，叙述の学み方や述定のあり方につ いての特徽はもたず，云䢖のあり方について のみ特徽を有するものと考えることができる。 そして，伝達されるべき話し手本来の意見は 叙述内容そのものの中に表わされているのて はなく, 話し手の心の中に秘められているも のとみなしうる。

さて，ここで改めてa/の表わす表 2 中の C項の意味, 及び ঐ\の表わす B項の意味を 粗かく分析してみると，表5のようになる。

表 5によれは，a／とる】とは层達に関し て，対立とみなせる程の明確な差異がみられ る。そこで，本報告ではょノの意䑶素を「自 分の意見に同意せよと迫る自我の押しつけ」 と考え，a】の意義素を「自分本来の意見を 吞みこんでしまう自我の消減」と考えること とした。

3.2.3 具体例での検証

前項で述へた
の考え方を以下，具体例に即して検証してみ る。

（i） 表 1 の10)(11にに父をつけた亩い方は， 非常に尊大な印象（例之は，答はわかりきっ ているのだというニュアンス）を聞き手に与 えるから，目上の人に対しては使わない方か よいといろ。それに对し，a】をつけた場合

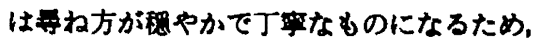
誰に対しても好感を与えるという。

(ii）表 1 の(12)では，、ノのみが用いられ

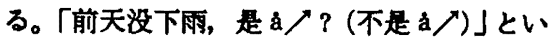
了表現の場合，話し手は实は叙述内容に反す る磷信（雨はふった）を抱いているにも拘わ らず, 表向きだけで「とろ思いますか？」と 寻ねている感しがするという。心の内を探れ は，筑問の形を借りながら押しつけをしてい るともみなすことができる。なお，「是か】」 は,「そうでしたか!」というあいつちの表 現として㥽用化されていて，念押し㩆問文の 中では用いることができない。

(iii) 表1の(4)において, a/が用いられ るのは,「老张勿という元気のいい呼びか けのみである。文脈の省略によって形つくら れる疑問 ((4)-c, (4)-d) には，その省略の方 法の如何に関わらず，用いられることがない。 疑問を表わす一定の形式が句に含まれている 場合（表1の(10)(11)）にはa/が用いられるこ とを考え合わせるならば，a/の意義素が疑 問といら一見排反しあう叙述の営みと共起す るためには，かえって疑問の定形を必要とす るといえる。この必要条件は, aノの伝える 話し手の意見が実は句の咅に秘められている ことから生じ特殊なものとみなさねばなら ない。一方，a文恃「老张文」において丁

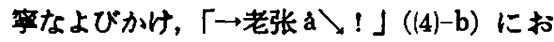
いて大きな彎ろき（ひいては疑問）を表わす。 やはり文脈の省略による疑問には用いられる ことがない。

$3.3 \mathrm{mà} \nearrow, \mathrm{må} \backslash$

3.3.1 må $ノ$ (高軽声), $\mathrm{må} \backslash$ (低蛏声)の形 
本報告て扱 $5 \mathrm{ma} / は$ ，従来の漠字表䟕て 「吗」によって表わされる音に対応している。 ところか，ma】については，漢字表䟕の 字として「席，应，䚈」が琵当する。また， 音形についてす，前音節の母音が前舌音であ る場合には me の形をとることがある。また 句末に用いられて，女性の甘えなとを表わす 場合なとには，怪声とはみなし得ない程には っきりした màつ発音が顥われる。

なお,インフォーマントの発音における måと må】の形の対比は，aノとa】の対 比と同しく，図 1 中に示した(A)タイプであっ た。

\section{$3.3 .2 \mathrm{må} /$, må \の意義来}

máノと må 】に関する内省報告を表 2 に照 らし合わせて概括し整理すると, ma゙は表 2 中のA項の一部「是非问」を表わし，mà はC項の意味を表わす。ただし，分句中ての $\mathrm{må}$, må】は，句音調の表面上の二つの意 味の違いに応してその意味に差異を生しるの で本項での整理からは徐外し，項を改めて考 察することにした。

さてここで, må/の表わす是非問の意味 をまず具体例を通して詳しく分析してみる。

(i ) 表1の(10)にはmaノがつけられない。 是非問を「一つに定められた叙述内容全体に ついて，一ヶ所以上の反事実，反真理がある かないかを舟ねる」むのとして捉えるならは， この言語事実は当然のことといえる。

(ii) 表 1 の(11)に måノなけて用いよう とすると，「什么」「谁」などはすべて不定詞 としての意味を表わすようになる ${ }^{16)}$ 。不定詞 は個を示さないとはいえ，ある種全体を指し 示すむのであるゆえ, 是非問の叙述内容に含 まれることができると考えられる。

(iii) 表 1 の(8)に måノをつけると，疑問 文となる。しかし，表 1 の(9)のうち，「别」 「面」を含む句には，ma/をつけることがで きない。それは、この二箪語が文単位 ${ }^{17)}$ の意 味を表わし，かつ，開き手に命令していると いう，ma/と排反する伝達の意味を表わす际 述副同であるためであると考えられる。この ような意味の共起反応は，同し陳述のレヘル で生しるものとみなせ，さらに「対立しあう 意味の排他反纳」として捉えることができる。

(iv) 表 1 の(3)に ma/をつけると，må】 をつけた場合よりむ一屋きつい表現になると いら。これは, 話し手が叙述の営みを理届や 事実に龿つき筋道だてて判断を下す意図に扰 って進めていることを，文脈によって充分に 示したうえで，なおかつ閒き手に判断をゆだ ねてみせる表現となる。そのため，開き手は 話し手のむつ倌念そのむのを受けいれるかと らかを迫られるようになると考えられる。こ のような意味の共起反応は，伝達と叙述とに わたって生しる共起反応のうち「問いかける 内容を叙述内容加話し手自身の意見へと変 换する反応」として捉えることができる。

（v）表 1 の(4)では, máノは, a,b, c につけて用いることができるこれらは皆, 主部を省略した形の疑問文と解釈でき，かつ， その主部も文脈・場面から容易に一つに定め ることができる。すなわち，

表 1 の(4)-a （在那儿的是）老张 må ?

表 1 の(4)-b (你说的是) 老张 $\mathrm{ma} /$ ?

表 1 の (4)-c (开会的时候儿是) 明天晚上 má

これに対し，(4)-c'には ma゙/がつけられな い。それは, 主部「你」のあとの述部が省略 されたままて，叙述内容が定められていない ため,すなわち、叙述の営みが末完了のため と考えられる。

次に，måつ表わす表 2 中のC項の意味 を具体例に即して検討していく。

（i）表 1 の(4)では，表 1 に規定された意 味を一つも表わすことができない。

表 1 の(4)-a ※老张 mà。

表 1 の(1)-h 你就是山田先生 må】。

(1)-h $\mathrm{h}$ は，配役を忘れた非骖を叱りつける 堨合などに使われる表現であるが、(4)-、は 
如何なる場合を想定してみても用いられない

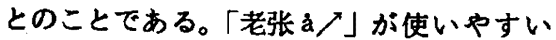
表現であることも考えあわせると，ma】の 表わす表 2 のC項の意味は，伝達のみならず 述定及び叙述内容についての特徽を意義素の 中に礁かに含んでいるものと考えられる。

（ii） mà】は多くの場合，柽蔍を含んだ ような高圧的な話しぶりを表わす。例えば， 表 1 の价においては（「什么」哪儿」などは 疑問詞として用いられる）高圧的に返事を促 すニュアンスを添える。また，表 1 の(8)-d で は、aノがこれから生しるであろうことへの 臨場感あふれる忠告を表わすのに対し，må 】はすんでしまったことへの䇾告を表わす。 すなわち,

表 1 の(8)-d 你要小心aノ! あなた，気をつけて! （方】は丁要になる）

表 1 の(8)-d 你要小心 må】!

あなた，気をつけないとタメ しゃないの!

(iii) ところが，mả】には子供等がしば しは使うような用法，すなわち闒き手に対し て自分の期待通りの返事や行動を求めるよう ない話しぶりを表わす場合がある。それは， 表 1 では(8)-a, b, c, (9)-a, b, (10)(11)においてて ある。これらの例に共通な要素は, 単語一つ に拠ってではなく, 単語連結のパターン（動 詞を主部なしの原型で用いることも含める) によって表わされる命令, 疑問の意味が叙述 内容に含まれていることである。筑問詞一つ を用いた疑問文や，禁止の副詞一つを用いた 禁止文に於ては, 期待の意味が生しないこと を考えあわせるならぼ，叙述の学みの如何が， må】の意味を表向き二つにわけているとい える。すなわち

表 1 の(10)-a・你明儿出去不出去 $\mathrm{må} \backslash$ ?

あなた，あした本当にでかけるのおノ

この叙述の営みの差巽を中国語の文法や意 味論の中でどのように位置つけるが ${ }^{183}$ は，大
きな文法課題と考えられるゆえ, 後日, 改め て考察することとする。

さて，ここで，må】の表わす二つの意味 について共通の意義特徽が含まれていないか を調へ，それにより一つの意義素をとり出せ ないか検討してみる。表 6 は，その検討結果 を示したものである。

表 6 に拠れば，må】は「話し手の僧念を 相手に押しつける」という唯一つの意毒莱を 有する一単語である。また，句の条件や具体 的用例の背影からみると，その棺念は，文脈 によって既に闒き手に充分伝えられているも のとみなすことができる(19)。したがって， må】の意義素には「叙述内容により, 話し 手の信念をつまびらかにする」という意義特 徵が含まれていると考えられる。そして本報 告では，その信念の押しつけ方としては「文 単位の単語連結のパターンを用いて訴える万 法が示されている場合，下手に出る態度を表 わす」という条件をつけておくにとどめる。

3.3 .3 分句中の má/と $\mathrm{må} \searrow$ 一間投詞 má の設定一

分句中における måノと må】の意味を検 討してみると，大きく二つのタイプに分ける ことができる。その区別を生しさせる前分句 の条件は，句音調】の意味を二タイプに分け るもの(表 4 中に示したA・Bのタイプ)と同 一である。そこで20)，分句中の má も句音調 と同しく叙述の営みを表わすものと考えられ る。

må ノと må】の二つの意味は次の通りであ る。

（i） 前分句の形が表 4 中のAタ1プの場 合，maノは「〜だとしてごらんなさいりと 誘いかけるニュアンスを表わす。その誘いは， 是否を問いかけるのではなく，閔き手にも叙 述の営みに参加するようにと呼びかけるもの である。また，må】は「〜だとする!…..」 という，それまでの確伊にみちた話しふりを 一旦停止することを表わす ${ }^{21}$ 。畐攵とと må】 
の意味の荤いは，次のような使われ方に顕著 に表わされている。

表 1 の(7)-c ·你要是做买实 mà, 可以发 财了。

表 1 の(7)-c' ※你要是做买实 ma \, 一定失 败。

内省翟告によれは，閏き手にとって不佮快

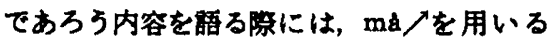
ことはあっても， ma】を用いることは避け るという。

（ii） 前分句の形が交 4 中のBタイプの域

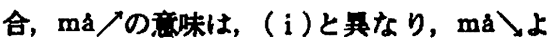
りむ更に押しつけがましくきつい曾い方を表 わす。må】の方は，(i)と同しく話し手の 自信の程を表わす。

さて, ここで, 分句中の $\mathrm{ma} / と \mathrm{ma} \backslash と$ は双方とも， $3 ・ 3 ・ 2$ 節で意素素を解明し た måノと ma】とは全く簧なった意味を表 わすことが明らかになる。さらに, 句音調ノ が表わす表问きの二つの意味を må八ニつ の意味と対照して考えるならほ，分句中の må/は唯一つの må の意味と句音調/の意 味とを同時に表わしているものとみなせる。 そして，その måの意味を(ii)に㧐って探る ならは，分句中の ma /と mà とは，句音調 フ、】が重ねられることにより二つの形にわ かれているものの，実際的には，一つの må であるとみなしろる。

すなわち，本祜告では分句中の må を叙述 の学みを表わす附属語22（「間投詞」と呼ふ） とし，その意辣来を「話し手が施道だてなが ら理詰で話しを進めていく」と考えることに する。

\section{4. まとめ}

本報告では，文音調ノ，】の意義美を述定

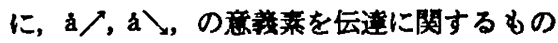
とみなした。そして, 語気詞 $\mathrm{ma} ノ, \mathrm{mà} \backslash を$ 各々別個に，述定と云连に関する意義素をも つものとし，さらに，間投詞 máを区別した。 次報では，ba ノ, ba】を，一つの語父同

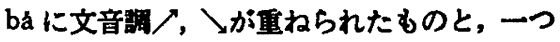

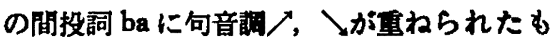

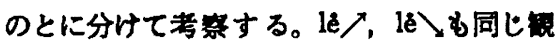
点から考察し，接統形式の léとの区別を明ら かにする。また, nå ノ，nå】は，一つの間投

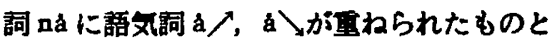
提えて考察する。de $ノ$, de】は一つの間投 詞déに文音毀ノ，】が重ねられたものとし て考察する。

ただし、これらの分析はインフォーマント の個人言語を対象として行なわれたものであ るので本誁告と異なった用例については，発 話者の言語経歴または方言を明示してお知ら せ斯けれは幸いです。また，文法詥について も個々の亩語事実の側から理論が左右される ことのないよろ注意はしましたが，大方の御 批即を仰ぐものです。

\section{(注)}

1）现代汉语语法讲话 1963, 王力 1956, 吕叔 湘 1944，等

2）趋元任 1968，孙德宣 1957，博良犁 1947， 等。これらの記述方法から一步脱却した考 察が上神 1968，で行なわれている。

3）芳贺 1954，渡辺 1971，を大筋において 踏まえた。ただし，形の名称として「句」 を用い，それに対応する意味の名称として 「叙述内容」を当てたこと「陳述」を形の 名称とし「述定」「伝達」を意味の名称とし て用いたことは，本報告独自の用法である。

4）服部 1951 (第九文音調)

5）大㜔 1975. 「中国語形容詞の意味分析」 中国語学 222. において用いた概念である。

6）大滰1975でのインフォーマントと同じ。

7）注1)2）の文献の他，岩波中国語辞典，中 国語学辞典 1958.（江南意店）

8）岩崎 1976 「存在判断の真理の基汻」參照

9）岩畸 1976 「価值判断の真理の基制」参照

10) C. J. Fillmore 1970. time of the loca- 
tionary 參照

11） 服部 1968. p 324

12）服部 1960. p 454

13）服部 1960. p 208 不定人称者, 参照

14）服部 1960. 第一人称者

15）趙元任 1968. p 812 814

16）呂叔湘 1944 （中） p 249

17）叙述の営みの中においても, 述部の頭 初で述定のあり方を指定する表現のあるこ とをみとめたい。当然，名詞句や副詞句の 中には収まらない。

18） 日本語については，南 1974 （第四立文 の構造）に具体的記述あり。

19) W.L. Chafe 1970. old information 参照

20）服部 1968，p 324 語義的呼応の作業原 則を踏まえた。

21）趙元任 1968, p 806.

22）服部 1960,p 461

\section{文献目錄}

现代汉语语法讲话 1963. 商务印书馆 王力1959.「中国现代语法」中华书局 吕叔湘 1944. 「中国文法要略」商务印书馆
趙元任 1968. 「A Grammer of Spoken Chinese」University of California Press. 孙德宣 1959. 「助词和叹词」新知识出版社 博良勲 1947.「助词的研究」 蒋维嵡, 殷焕先 1959. 「字调和语调」新知识 出版社

上神忠彦 1968. 「文末語匃助詞類内連用のき まりについて」中国語学 179

芳贺綏 1954.「陣述とは何もの? 」国語国文 4 佐治圭三 1957.「終助詞の機能」国語国文26 $-7$

渡辺実 1971. 「国語粠文論」塔害房

南不二夫 1974. 「現代日本語の粠造」大修館 Pierre Guiraud 1951. 「LA SÉMIOLOGIE」 佐藤信夫訳 白水社

岩绮武雄 1976 「真理論」東京大学出版会 服部四郎 1951. 「音声学」岩波全粪 服部四郎 1960.「翌語学の方法」岩波蓉店 服部四郎 1968.「意味」岩波哲学諈座「言語」 Charles J. Fillmore: 1970 「Types of lexical information」Studies in Syntax and Semantics

Wallace L. Chafe 1970 「Structure of Language $\rfloor$ The University of Chicago Press.

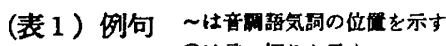

○は茴い切りを示す

（）内は句の中のポイントく 内は场面

\begin{tabular}{|c|c|}
\hline $\begin{array}{l}\text { (1)平叙文にな } \\
\text { クすい句 }\end{array}$ & $\begin{array}{l}\text { a. (現在) 你知道 。 b. (過去) 我告诉过你 。 } \\
\text { c. (未来) 他们明天走 。 d. (確実) 他是昨天到的 。 } \\
\text { e. (否定) 我並没做错 。 f . (否定) 这绝不是他做的 。 } \\
\text { g. (数詞) 我原来有两个斯确 。 } \\
\text { h. (才) 今天的晚会十点钟才开完 。 } \\
\text { i. (就) 您就是山田先生 。 j. (在) 美国在太平洋的东边儿 。 }\end{array}$ \\
\hline $\begin{array}{l}\text { (2)提案を示す } \\
\text { 文になりやす } \\
\text { い句 }\end{array}$ & $\begin{array}{l}\text { a. 我跟你去查 。 b. 我们就这么办 。 } \\
\text { b. 你们都不用去了, 我送白师傅回去 。 }\end{array}$ \\
\hline $\begin{array}{l}\text { (3)反詰を示す } \\
\text { 文になりやす }\end{array}$ & $\begin{array}{l}\text { a. (否定詞) 事情出在你们院子里, 你会不知道 。 } \\
\text { b. (还) 这一首还能说它不好 。 }\end{array}$ \\
\hline
\end{tabular}




\begin{tabular}{|c|c|}
\hline W句 & c.（疑問鵘）你怎么不去〜。 \\
\hline $\begin{array}{l}\text { (4)名詞一語文 } \\
\text { となる句 }\end{array}$ & 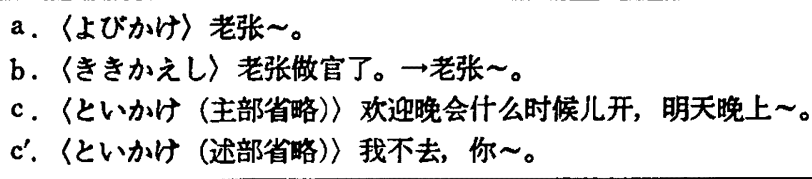 \\
\hline $\begin{array}{l}\text { (5)名詞一磸て } \\
\text { 列挙, 提題を } \\
\text { 示す句 }\end{array}$ & $\begin{array}{l}\text { a. 对于交际 ，礼节 ，应该你不大熱悉。 } \\
\text { b. 这个 ，对不对。 } \\
\text { c. 钱 ，钱用光了，事情 ，事情没做。 }\end{array}$ \\
\hline $\begin{array}{l}\text { (6)対句, 因果 } \\
\text { を示す分句 }\end{array}$ & 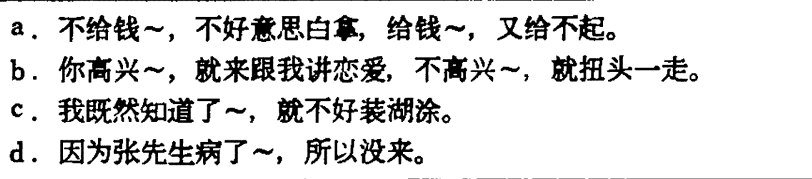 \\
\hline $\begin{array}{l}\text { (7)例示, 仮定 } \\
\text { を示す分句 }\end{array}$ & 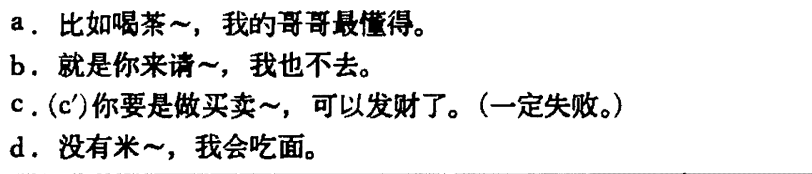 \\
\hline $\begin{array}{l}\text { (8)命令文にな } \\
\text { クすい句 }\end{array}$ & $\begin{array}{l}\text { a. 来 ! } \quad \text { b. 快点儿走 ! } \\
\text { c. 这里不要你, 你去 ～！ d. 你要小心 。 }\end{array}$ \\
\hline $\begin{array}{l}\text { (9)禁止文にな } \\
\text { りやい句 }\end{array}$ & $\begin{array}{ll}\text { a. 你们别闹 ～～} & \text { b. 那个你甬给钱了 。 } \\
\text { c. 你不去 。 } & \text { d. 这倒是很危险 。 }\end{array}$ \\
\hline (10)選択疑問 & $\begin{array}{l}\text { a. 你明儿出去不出去 ? b. 可以不可以这样提出问题 ? } \\
\text { c. 你看见了他, 没有 ? }\end{array}$ \\
\hline $\begin{array}{l}\text { (1)特指問にな } \\
\text { クやすい句 }\end{array}$ & $\begin{array}{l}\text { a. 你都到过哪儿 ～？ b. 你到底要干什么 ？ } \\
\text { c. 有什么事 ? (说出来咱们商量。） }\end{array}$ \\
\hline $\begin{array}{l}\text { (12)念入れ筑問 } \\
\text { になりすい } \\
\text { 句 }\end{array}$ & a. ( $\left.a^{\prime}\right)$ 前天没下雨, 是 (不是) ～? \\
\hline $\begin{array}{l}\text { (13)あいつち, } \\
\text { 回答文となる } \\
\text { 句 }\end{array}$ & $\begin{array}{l}\text { a. } \rightarrow \text { 是 , 这种也是一类。 } \\
\text { b. 那个人姓王吗? } \rightarrow \text { 不, 他姓李 。 } \\
\text { c. 他不快活吧? } \rightarrow \text { 不, 他快活 。 }\end{array}$ \\
\hline
\end{tabular}

（表 2）表 1 の(1)に顥われる意味

\begin{tabular}{|c|c|c|c|}
\hline 分類名 & 代表的な表現 & * 述定に関する意垡特徵 & 伝達に関する意義特徵 \\
\hline A 項 & $\begin{array}{l}\sim \text {, 是不是? 请 } \\
\text { 佨详细告诉我。 } \\
\text { 再说一遍 }\end{array}$ & $\begin{array}{l}\text { 確信なし } \\
\text { 不信を抱いている。 } \\
\text { 確信なし。 }\end{array}$ & $\begin{array}{l}\text { 相手に判定を任せる。 } \\
\text { 相手に説明を求める。 } \\
\text { 相手に繰返しを求める。 }\end{array}$ \\
\hline
\end{tabular}




\begin{tabular}{|c|c|c|c|}
\hline $\begin{array}{l}\text { B 項 } \\
\text { B }^{\prime} \text { 項 }\end{array}$ & $\begin{array}{l}\text { 意外・感嘆 } \\
\text { 肯定 }\end{array}$ & $\begin{array}{l}\text { **発話時点で確信をむつ } \\
\text { 確信をむつ。 }\end{array}$ & $\begin{array}{l}\text { （積㮒的には）求めない } \\
\text { 相手に何も求めない }\end{array}$ \\
\hline C 項 & $\begin{array}{l}\text { 分 } \\
\text { 反 詰 } \\
\text { 命 令 }\end{array}$ & $\begin{array}{l}\text { 確悟をむつ } \\
\text { 強い確怊をむつ } \\
\text { 強い確信をむつ }\end{array}$ & $\begin{array}{l}\text { 相手に了解を求める } \\
\text { 相手に同意を求める。 } \\
\text { 相手に行為を求める。 }\end{array}$ \\
\hline
\end{tabular}

（表 3）文音調ノ，】の大ざっぱな意味

\begin{tabular}{|c|c|c|}
\hline （表 1）中の例句番号 & 文音調厂（強調） & 文音調】（強調） \\
\hline $\begin{array}{l}(1)(2)(3)(4), \\
(8) / 9) /(12)(13)\end{array}$ & 表 2 のA項 $\stackrel{*}{*}$ 項 $)$ & 表 2のB'項（C項） \\
\hline$(10)(11)$ & 表 2 のC項 & 平常の霋ね方 \\
\hline
\end{tabular}

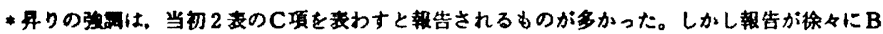

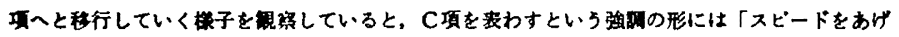
る」といら要来が加わっていたことがわかった。

（表 4）句音調ノ，】の意味

\begin{tabular}{|c|c|c|c|c|}
\hline 偂 & (表 1) 中の例句番号 & 前分句の特徴 & 句音調ノの意味 & 句音調】の意味 \\
\hline $\begin{array}{l}\mathrm{A} \\
\text { 多 } \\
1 \\
7\end{array}$ & $\begin{array}{l}(5) \\
(6)-a, b \\
(7)^{*}-c, c^{\prime}, d\end{array}$ & $\begin{array}{l}\text { 後に続くか } \\
\text { とろかわからない } \\
\text { (接繶詞なし) }\end{array}$ & $\begin{array}{l}\text { 言い切りではなく } \\
\text { 後に続くような } \\
\text { 表現となる }\end{array}$ & $\begin{array}{l}\text { 言い切りであるかの } \\
\text { 如き表現となる }\end{array}$ \\
\hline $\begin{array}{l}\text { B } \\
\text { 多 } \\
7 \\
7\end{array}$ & $\begin{array}{l}(6)-b, \quad c \\
(7)-a, b\end{array}$ & $\begin{array}{l}\text { 後に続くこと } \\
\text { がわかる }\end{array}$ & $\begin{array}{l}\text { 切り口上な話し } \\
\text { ぶりになる }\end{array}$ & $\begin{array}{l}\text { 落ち着いた話し } \\
\text { ぶりになる }\end{array}$ \\
\hline
\end{tabular}

*(7)-c, c'1列外である。この点については後にふれる。

（表 5）a /とå】の意我特徽

\begin{tabular}{|c|c|c|}
\hline & 述定に関する意義特徵 & 伝達に関する意義特徵 \\
\hline $\mathbf{a} \nearrow$ & $\begin{array}{l}\text { はっきりした自分の意見をむつ } \\
\text { ゆえ, 当然叙述内容に対しても } \\
\text { 一定の見解を生しる。 }\end{array}$ & $\begin{array}{l}\text { 自分の意見に聞き手を } \\
\text { 同意させようとする。 }\end{array}$ \\
\hline à & $\begin{array}{l}\text { 発話時点において, 新たな意見 } \\
\text { をむち, 叙述内容に対しても新 } \\
\text { たな見解を生しる。 }\end{array}$ & $\begin{array}{l}\text { 本来の自分の意見として, } \\
\text { 押し出さないようにする。 }\end{array}$ \\
\hline
\end{tabular}

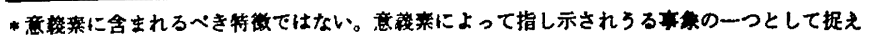
ろのが妥当である。 
（表 6）må】の表わす二つの意味の意偖特徽

\begin{tabular}{|c|c|c|c|}
\hline & 前分句の条件 & 述定 & （対人组情） \\
\hline $\begin{array}{l}W 5 \\
\text { WE }\end{array}$ & 述部 & $\begin{array}{l}\text { 活し手はある意見をは } \\
\text { っきり持っている }\end{array}$ & $\begin{array}{l}\text { 聞き手を自分の } \\
\text { 意見に同意させたい（高圧的） }\end{array}$ \\
\hline 期待 & 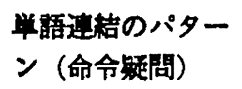 & 上に同し & 上に同し（下手に出る） \\
\hline
\end{tabular}

